\title{
ウンシュウミカンにおける果汁の糖度と次年度生産性との関係
}

\author{
岡田正道 ${ }^{\mathrm{a} *}$ ・高橋哲也 $\mathrm{b}$ \\ 静岡県柑橘試験場４24-0905 静岡市清水区駒越西
}

\section{Relationship between Concentration of Soluble Solids in Fruit Juice and Productivity of the Next Year in Satsuma Mandarin}

\author{
Masamichi Okada ${ }^{\mathrm{a} *}$ and Tetsuya Takahashi ${ }^{\mathrm{b}}$ \\ Shizuoka Citrus Experiment Station, Shimizu, Shizuoka 424-0905
}

\begin{abstract}
In several satsuma mandarin (Citrus unshiu Marc.) cultivars, the parameters of productivity (flowering, fruiting, yield, etc.) of one year correlated negatively with those of the next year, while the fruit weight and concentration of soluble solids in fruit juice of one year correlated positively with the productivity parameters of the next year. Our multiple regression analyses demonstrate that the concentration of soluble solids is an effective second factor, whereas fruit load is the main factor associated with productivity of the next year. The relation was clearer in cultivars with more variable yields. In those cultivars, the flowering intensity of the next year tended to increase in parallel with increase in the concentration of soluble solids, and the number of set fruit and yield showed similar relations at least until a concentration of about $12 \%$ soluble solids. These findings indicate that the concentration of soluble solids is a useful parameter for estimating the productivity of the next year and appropriately high fruit quality might correlate with high productivity.
\end{abstract}

Key Words : flowering intensity, fruit quality, fruit set, yield

キーワード：着花程度，果実品質，結実，収量

\begin{abstract}
緒 言
ウンシュウミカン，特に高糖系といわれる ‘青島温州’ などは隔年結果しやすい上に，消費者の高品質志向を十分 飞満足させる食味でない場合も多く, 果実の高品質化と安 定生産が重要な課題となっている。生産現場に和ける高品 質化と安定生産の関係は単純ではなく, 高品質化が隔年結 果を助長したと考兄られる場合や，高品質化と安定生産が 両立していると考光られる場合などさまざまであるが， 個々の事例を少数の指標に基づく一連の現象として捉える ことができれば，高品質化技術導入をさらに促進するらえ で有効と考兄られる。これまでのウンシュウミカンでの報 告は，土壤水分制御（富田，1972a, b), 着果量と摘果（森 岡，1987，1988），樹別や枝別の隔年交互結実方法（木原ら， 1995; 宮田・橋本，2002）などの環境制御や結実管理の結 果として当年の果実品質や次年度の生産性が論じられるこ とが多く, 果実品質と次年度の生産性との関係を直接論じ

2005 年 8 月 29 日 受付. 2006 年 2 月 20 日 受理.

本報告の概要は平成 16 年度秋季大会で発表した。

* Corresponding author.

a 現在 : 静岡県経済農業協同組合連合会

b 現在 : 静岡県西部農林事務所
\end{abstract}

た報告は見当たらない，果実はシンク能が高く（清水ら， 1976)，さまざまな自然的・栽培技術的要因の影響を受けや すいとみられることから，果実品質，特に糖度は，炭水化 物などの樹体養分 (Goldschmidt•Golomb, 1982; 岡田, 2004) と同様に，樹体の生理状態を表す指標のひとつになり得る ものと筆者らは想定した，そこで，手始めとして自然条件 下に扔或事例から，糖度と次年度の生産性との関係につ いて明確化を試みた。

\section{材料および方法}

試験 1 ：“宮川早生”，“繁田温州’および ‘青島温州’の解析 (1976 1986)

1976 年に 10 年生 “宮川早生”，“繁田温州’および ‘青島 温州’各 4 樹を用い, 1986 年までの 11 年間にわたって, 着 花程度, 生理落果後の結実数, 収穫果数, 収量, 果実重, 果汁の糖度を調査した。着花程度は達観により無（0）から 多（5）とした．着花程度と抽出枝の実測による葉花比との 関係は第 1 図のと打りで，着花程度は葉花比の 2 を底とす る対数とほ涪直線関係にあり, 着花程度 $5 ， 4 ， 3 ， 2 ， 1$ に 対する葉花比の対数は $0 ， 1 ， 2 ， 3 ， 4$ 程度，すなわち実数 としては，1，2，4，8，16程度である．生理落果後の結実 数, 収穫果数, 収量は実測し, 樹冠占有面積 $1 \mathrm{~m}^{2}$ 当たりに 
換算した. 生理落果後の結実数が多い場合は, “宮川早生” および ‘青島温州’ は葉果比 30 程度, “繁田温州’ 25 程度 を目安に摘果を行った. 収穫時期の基準日を“宮川早生”は

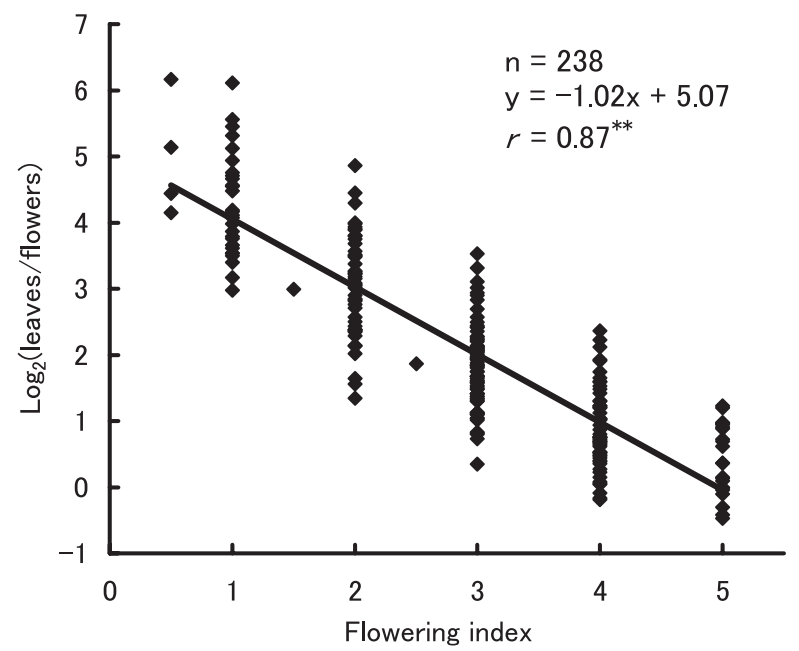

Fig. 1 Relationship between flowering index and number of leaves per flower in satsuma mandarin. Four branches about $50 \mathrm{~cm}$ length were sampled per tree and the leaves and flowers of the branchs were totaled to calculate leaves/ flowers of the tree.

$* *$ indicates significance at $1 \%$ level.
11 月 5 日, “繁田温州’ は 11 月 20 日, “青島温州’ は 12 月 5 日 とし，扣括を社基準日から 1 週間以内に収穫した。果汁の 糖度は, 1 樹あたり $5 \sim 10$ 果をまとめて搾汁し，屈折糖度 計によるBrix 值として示した。糖度は，9月以降月 2 回の 定期日と収穫時に調査しており，基準日に調査がない場合 は前後の推移から基準日の值を推定した。果実重は収量／ 収穫果数で求めた。

\section{試験 2 : 隔年結果誘導処理を加えた ‘青島温州” の解析 (1982 1985)}

1982 年に 16 年生の ‘青島温州’ 47 樹について, 1985 年ま での 4 年間, 試験 1 と同様の方法により調査した. ただし, 隔年結果の影響と年度に共通の気象などの影響を極力分離 するため, 初年度に半数を裏年樹としてスタートさせるこ ととし, 葉果比 45 程度を目標に強めの摘果を行った樹もあ る. 収穫および果実分析は 12 月中旬で，収穫時期による糖 度補正は行っていない。

なお，試験 1 执よび試験 2 ともに，着花程度，結実数， 収穫果数执よび収量を生産性項目，果実重および糖度を果 実形質項目と総称することがある。 また，施肥は静岡県の 施肥基準に沿って実施した。

\section{結 果}

各調査項目の平均值と変動係数を第 1 表に示した.さら

Table 1 Averages and ranges of various parameters of productivity and fruit characterics in several satsuma mandarin cultivars.

\begin{tabular}{|c|c|c|c|c|c|c|c|}
\hline \multirow{2}{*}{ Experiment } & \multirow{2}{*}{ Cultivar } & \multirow{2}{*}{ Parameter } & \multirow{2}{*}{ Ave. ${ }^{z}$} & \multirow{2}{*}{$\mathrm{CV}(\%)^{\mathrm{y}}$} & \multicolumn{3}{|c|}{ Share of variation $(\%)$} \\
\hline & & & & & Tree & Year & Tree $\times$ Year \\
\hline \multirow{18}{*}{$\begin{array}{c}1 \\
(n=44)\end{array}$} & \multirow[t]{6}{*}{ Miyagawa wase } & Flowering index $(0 \sim 5)$ & 3.7 & 23.9 & 3.0 & 53.8 & 43.2 \\
\hline & & Set fruit (number $/ \mathrm{m}^{2}$ ) & 196.5 & 31.9 & 15.2 & 46.0 & 38.8 \\
\hline & & Harvested fruit (number $/ \mathrm{m}^{2}$ ) & 95.5 & 29.2 & 6.6 & 57.6 & 35.8 \\
\hline & & Yield $\left(\mathrm{kg} / \mathrm{m}^{2}\right)$ & 10.92 & 29.2 & 8.4 & 64.0 & 27.6 \\
\hline & & Average fruit weight $(\mathrm{g})$ & 115.8 & 16.4 & 16.4 & 41.9 & 41.7 \\
\hline & & Soluble solids content $(\%)$ & 10.39 & 10.8 & 7.9 & 74.8 & 17.3 \\
\hline & \multirow[t]{6}{*}{ Shigeta unshu } & Flowering index $(0 \sim 5)$ & 2.0 & 39.9 & 0.7 & 55.3 & 44.0 \\
\hline & & Set fruit (number $/ \mathrm{m}^{2}$ ) & 126.7 & 41.5 & 5.8 & 43.8 & 50.4 \\
\hline & & Harvested fruit (number $/ \mathrm{m}^{2}$ ) & 83.5 & 38.2 & 6.8 & 46.5 & 46.7 \\
\hline & & Yield $\left(\mathrm{kg} / \mathrm{m}^{2}\right)$ & 10.82 & 33.4 & 10.6 & 48.4 & 41.0 \\
\hline & & Average fruit weight $(\mathrm{g})$ & 133.7 & 12.9 & 1.3 & 45.2 & 53.5 \\
\hline & & Soluble solids content $(\%)$ & 9.97 & 8.6 & 8.9 & 70.2 & 20.9 \\
\hline & \multirow[t]{6}{*}{ Aoshima unshu } & Flowering index $(0 \sim 5)$ & 2.1 & 66.0 & 1.8 & 33.6 & 64.6 \\
\hline & & Set fruit (number $/ \mathrm{m}^{2}$ ) & 73.3 & 52.1 & 0.3 & 27.4 & 72.3 \\
\hline & & Harvested fruit (number $/ \mathrm{m}^{2}$ ) & 56.4 & 47.2 & 0.4 & 34.8 & 64.8 \\
\hline & & Yield $\left(\mathrm{kg} / \mathrm{m}^{2}\right)$ & 7.68 & 40.4 & 0.6 & 49.2 & 50.2 \\
\hline & & Average fruit weight $(\mathrm{g})$ & 143.5 & 14.6 & 2.4 & 21.5 & 76.1 \\
\hline & & Soluble solids content $(\%)$ & 11.12 & 7.4 & 9.0 & 72.9 & 18.1 \\
\hline \multirow{6}{*}{$\begin{array}{c}2 \\
(\mathrm{n}=188)\end{array}$} & \multirow[t]{6}{*}{ Aoshima unsyu } & Flowering index $(0 \sim 5)$ & 2.5 & 45.7 & 6.5 & 12.6 & 80.9 \\
\hline & & Set fruit (number $/ \mathrm{m}^{2}$ ) & 82.4 & 61.5 & 8.9 & 49.4 & 41.7 \\
\hline & & Harvested fruit (number $/ \mathrm{m}^{2}$ ) & 49.6 & 42.3 & 14.3 & 34.7 & 51.0 \\
\hline & & Yield $\left(\mathrm{kg} / \mathrm{m}^{2}\right)$ & 6.27 & 36.4 & 27.4 & 27.7 & 44.9 \\
\hline & & Average fruit weight $(\mathrm{g})$ & 129.3 & 15.3 & 25.0 & 47.9 & 27.1 \\
\hline & & Soluble solids content $(\%)$ & 11.30 & 10.2 & 13.7 & 66.9 & 19.4 \\
\hline
\end{tabular}

\footnotetext{
${ }^{\mathrm{z}}$ Average.

${ }^{\mathrm{y}}$ Coefficient of variation.
} 
に，変動の平方和に占める樹間変動，年次間変動和よびそ の交互作用の割合も示した。試験 1 の品種別にみた生産性 項目 (着花程度, 結実数, 収穫果数, 収量) では, 平均值は “宮川早生”が大きく, ‘青島温州” が小さい傾向で, 変動 係数（CV）は“宮川早生”が小さく，“青島温州”が大きい 傾向であった. 果実重では, 平均值は“宮川早生”が小さく, “青島温州”が大きかったが，変動係数には大差なかった。 糖度では, 平均值は ‘繁田温州’ が低く, “青島温州”が高 かったが, 変動係数は “宮川早生”が大きく, “青島温州”が
小さい傾向であったまたた，全変動に占める樹間変動の割 合は 3 品種ともにどの項目も小さかった．年次間変動の割 合は概して “宮川早生’で大きく，“青島温州’で小さい傾向 であったが，糖度はどの品種でも年次間変動の割合が大き く,70\%を超えていた. 試験 2 では, 着花程度において年次 間変動の割合が小さかったこと，収量と果実重において樹 間変動の割合が大きかったことなどの点が試験 1 の結果と は異なったが，糖度は試験 1 と同様に年次間変動の割合が 大きかった。な扣，同一年における生産性項目と糖度との

Table 2 Simple and multiple correlation coefficients between various parameters of productivity and fruit characteristics (explanatory variable) and parameters of productivity for the next year (objective variable) in several satsuma mandarin cultivars.

\begin{tabular}{|c|c|c|c|c|c|c|c|c|c|}
\hline \multirow{3}{*}{ Experiment } & \multirow{3}{*}{ Cultivar } & \multirow{3}{*}{ Objective variable $(\mathrm{Y})$} & \multicolumn{7}{|c|}{ Explanatory variable $(\mathrm{X})$} \\
\hline & & & \multicolumn{6}{|c|}{ Simple } & \multirow{2}{*}{$\frac{\text { Multiple }}{\text { All }}$} \\
\hline & & & $\mathrm{FI}^{\mathrm{z}}$ & $\mathrm{SF}^{\mathrm{y}}$ & $\mathrm{HF}^{\mathrm{x}}$ & $\mathrm{YD}^{\mathrm{w}}$ & $\mathrm{FW}^{\mathrm{v}}$ & $\mathrm{SS}^{\mathrm{u}}$ & \\
\hline \multirow{9}{*}{$\begin{array}{c}1 \\
(n=40)\end{array}$} & Miyagawa wase & FI & $-0.33 *$ & -0.15 & -0.10 & 0.08 & 0.29 & 0.22 & $0.56^{*}$ \\
\hline & & $\mathrm{SF}$ & -0.11 & 0.06 & 0.24 & $0.37 *$ & 0.26 & -0.17 & 0.42 \\
\hline & & YD & 0.25 & 0.11 & $0.33 *$ & $0.34 *$ & 0.03 & -0.21 & 0.49 \\
\hline & Shigeta unsyu & FI & $-0.55 * *$ & $-0.46^{* *}$ & $-0.45 * *$ & -0.31 & $0.67 * *$ & $0.38 *$ & $0.80 * *$ \\
\hline & & SF & $-0.52 * *$ & $-0.32 *$ & -0.28 & -0.09 & $0.65 * *$ & $0.39 *$ & $0.83 * *$ \\
\hline & & YD & $-0.35 *$ & -0.13 & -0.15 & 0.03 & $0.59 * *$ & $0.32 *$ & $0.81 * *$ \\
\hline & Aoshima unsyu & FI & $-0.79 * *$ & $-0.81 * *$ & $-0.71 * *$ & $-0.60 * *$ & $0.70 * *$ & 0.26 & $0.88 * *$ \\
\hline & & SF & $-0.61 * *$ & $-0.61 * *$ & $-0.47 * *$ & -0.29 & $0.63 * *$ & $0.33 *$ & $0.82 * *$ \\
\hline & & YD & $-0.50 * *$ & $-0.49 * *$ & -0.31 & -0.08 & $0.62 * *$ & $0.33 *$ & $0.87 * *$ \\
\hline \multirow{3}{*}{$\begin{array}{c}2 \\
(n=151)\end{array}$} & Aoshima unsyu & FI & $-0.68 * *$ & $-0.73 * *$ & $-0.69 * *$ & $-0.55 * *$ & $0.61 * *$ & $0.59 * *$ & $0.86 * *$ \\
\hline & & $\mathrm{SF}$ & $-0.41 *$ & -0.14 & -0.14 & 0.02 & $0.38 * *$ & 0.08 & $0.68 * *$ \\
\hline & & YD & $-0.46 * *$ & $-0.37 * *$ & $-0.28 * *$ & -0.05 & $0.65 * *$ & $0.32 * *$ & $0.80 * *$ \\
\hline
\end{tabular}

${ }^{\mathrm{z}} \mathrm{FI}$ : flowering index. ${ }^{\mathrm{y}} \mathrm{SF}$ : set fruit. ${ }^{\mathrm{x}} \mathrm{HF}$ : harvested fruit.

${ }^{\mathrm{w}}$ YD: yield. ${ }^{\mathrm{v}} \mathrm{FW}$ : fruit weight. ${ }^{\mathrm{u}} \mathrm{SS}$ : soluble solids.

$*$ and $* *$ indicate significance at $5 \%$ and $1 \%$ levels, respectively.

Table 3 Multiple correlation analysis showing the most and almost equally effective combinations of two explanatory variables for the productivity in the next year for several satsuma mandarin cultivars.

\begin{tabular}{|c|c|c|c|c|c|c|c|c|}
\hline \multirow{3}{*}{ Experiment } & \multirow{3}{*}{ Cultivar } & \multirow{3}{*}{$\begin{array}{c}\text { Objective variable } \\
\text { Next year } \\
\mathrm{Y}\end{array}$} & \multirow{2}{*}{\multicolumn{2}{|c|}{$\begin{array}{c}\text { Explanatory variable } \\
\text { One year }\end{array}$}} & \multirow{3}{*}{ Regression form } & \multicolumn{3}{|c|}{ Correlative coefficient } \\
\hline & & & & & & \multicolumn{2}{|c|}{ Partial } & \multirow{2}{*}{$\begin{array}{c}\text { Multiple } \\
\mathrm{R}\end{array}$} \\
\hline & & & $\mathrm{X}_{1}$ & $\mathrm{X}_{2}$ & & $\mathrm{X}_{1}$ & $\mathrm{X}_{2}$ & \\
\hline \multirow{10}{*}{$\begin{array}{c}1 \\
(\mathrm{n}=40)\end{array}$} & Miyagawa wase & $\mathrm{FI}^{\mathrm{z}}$ & $\mathrm{FW}^{\mathrm{w}}$ & $\mathrm{SS}^{\mathrm{v}}$ & $\mathrm{Y}=0.0204 \mathrm{X}_{1}+0.309 \mathrm{X}_{2}-1.99$ & $0.43 * *$ & $0.39 *$ & $0.48 * *$ \\
\hline & & $\mathrm{SF}^{\mathrm{y}}$ & YD & FW & $Y=6.38 X_{1}+0.582 X_{2}+55.4$ & $0.33 *$ & 0.19 & $0.41 *$ \\
\hline & & $\mathrm{YD}^{\mathrm{x}}$ & YD & FI & $\mathrm{Y}=0.324 \mathrm{X}_{1}+0.878 \mathrm{X}_{2}+4.02$ & $0.34 *$ & 0.24 & $0.41 *$ \\
\hline & Shigeta unsyu & FI & FW & SS & $\mathrm{Y}=0.0348 \mathrm{X}_{1}+0.358 \mathrm{X}_{2}-6.11$ & $0.73 * *$ & $0.52 * *$ & $0.77 * *$ \\
\hline & & SF & FW & SS & $\mathrm{Y}=2.25 \mathrm{X}_{1}+24.2 \mathrm{X}_{2}-409.1$ & $0.71 * *$ & $0.52 * *$ & $0.76 * *$ \\
\hline & & YD & FW & SS & $\mathrm{Y}=0.139 \mathrm{X}_{1}+1.36 \mathrm{X}_{2}-20.98$ & $0.63 * *$ & $0.40 *$ & $0.67 * *$ \\
\hline & Aoshima unsyu & FI & FI & FW & $Y=-0.569 X_{1}+0.021 X_{2}+0.44$ & $-0.63 * *$ & $0.40 *$ & $0.83 * *$ \\
\hline & & FI & FI & SS & $Y=-0.755 X_{1}+0.366 X_{2}-0.20$ & $-0.81 * *$ & $0.34 *$ & $0.82 * *$ \\
\hline & & $\mathrm{SF}$ & FW & SS & $\mathrm{Y}=1.29 \mathrm{X}_{1}+21.8 \mathrm{X}_{2}-351.0$ & $0.73 * *$ & $0.55 * *$ & $0.76 * *$ \\
\hline & & YD & FW & SS & $\mathrm{Y}=0.103 \mathrm{X}_{1}+1.74 \mathrm{X}_{2}-26.43$ & $0.72 * *$ & $0.54 * *$ & $0.75 * *$ \\
\hline \multirow{3}{*}{$\begin{array}{c}2 \\
(n=151)\end{array}$} & Aoshima unsyu & FI & FI & SS & $Y=-0.552 X_{1}+0.422 X_{2}-1.05$ & $-0.73 * *$ & $0.65 * *$ & $0.83 * *$ \\
\hline & & SF & FI & YD & $Y=-19.1 X_{1}+5.802 X_{2}+71.6$ & $-0.53 * *$ & $0.37 * *$ & $0.53 * *$ \\
\hline & & YD & FW & FI & $\mathrm{Y}=0.0546 \mathrm{X}_{1}-0.528 \mathrm{X}_{2}-0.02$ & $0.60 * *$ & $-0.37 * *$ & $0.71 * *$ \\
\hline
\end{tabular}

${ }^{\mathrm{z}}$ FI: flowering index. ${ }^{\mathrm{y}} \mathrm{SF}$ : set fruit. ${ }^{\mathrm{x}}$ YD: yield.

${ }^{\mathrm{w}} \mathrm{FW}$ : fruit weight. ${ }^{\mathrm{v}} \mathrm{SS}$ : soluble solids.

$*$ and $* *$ indicate significance at $5 \%$ and $1 \%$ levels, respectively. 

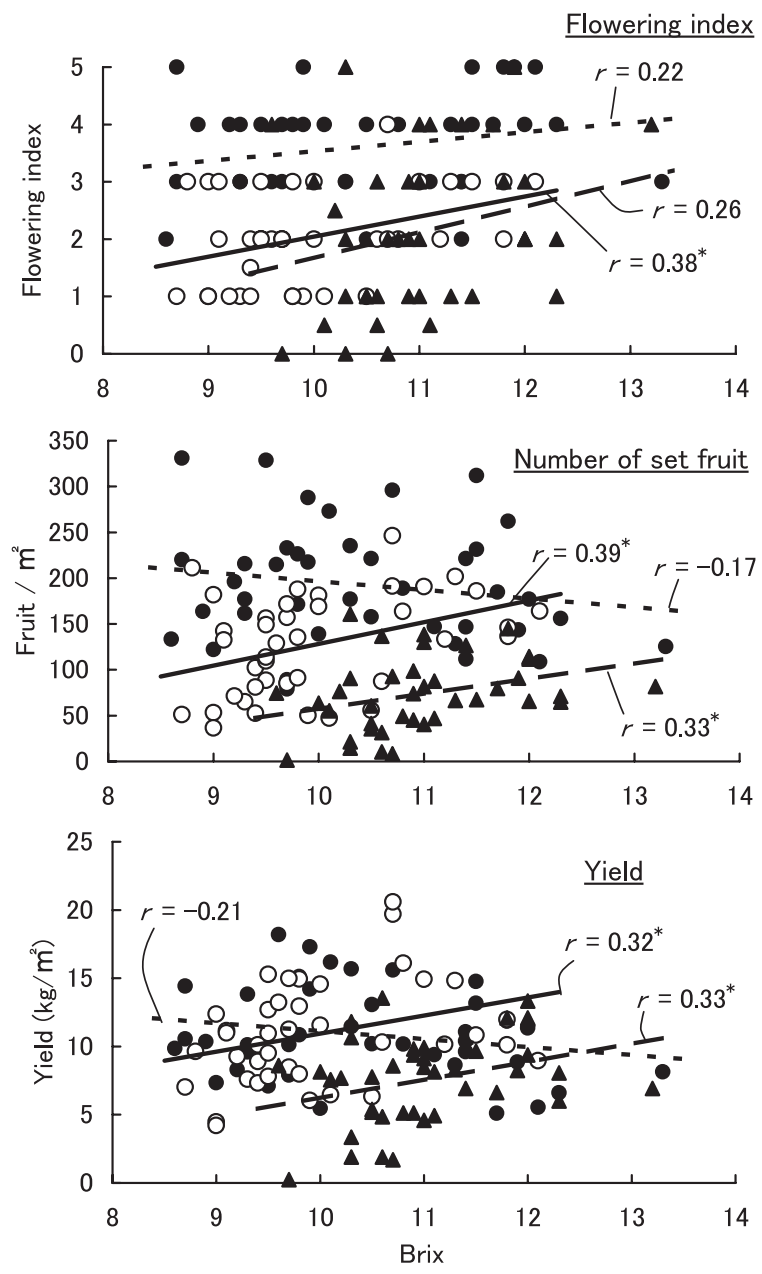

Fig. 2 Relationships between concentration of soluble solids (Brix) in fruit juice and productiviy in the next year for several satsuma mandarin cultivars.

* indicates significance at $5 \%$ level.

- Miyagawa wase $\bigcirc$ Shigeta unshu A Aoshima unshu - - - - Miyagawa wase $\longrightarrow$ Shigeta unshu

- Aoshima unshu

相関関係は全般に小さかった（データ略）.

生産性項目（着花程度, 結実数, 收穫果数, 収量) と果実 形質項目 (果実重, 糖度) を説明変数, 次年度の生産性項目 (着花程度, 結実数, 収量) を目的変数とした両者の間の単 相関係数抒よび重相関係数を第 2 表に示した。試験 1 の単 相関係数は, “宮川早生”では全般的に相関係数が低かった。 “繁田温州’ と ‘青島温州’ では, 生産性項目は次年度の生産 性項目々負の相関がみられ, 特に “青島温州”で相関係数が 高かった. また, 説明変数, 目的変数ともに着花程度が関係 する相関係数は高く, 結実数や収量が関係する相関係数は 低い傾向であった。一方, 果実重は次年度の生産性項目と 強い正の相関が認められ, 糖度も正の相関関係がみられた。 重相関係数も, “宮川早生”では低く, “繁田温州’ ‘青島 温州’では高かった. 試験 2 では, 次年度の着花程度に対し ては, 試験 1 同様生産性項目は強い負の相関が認められ,
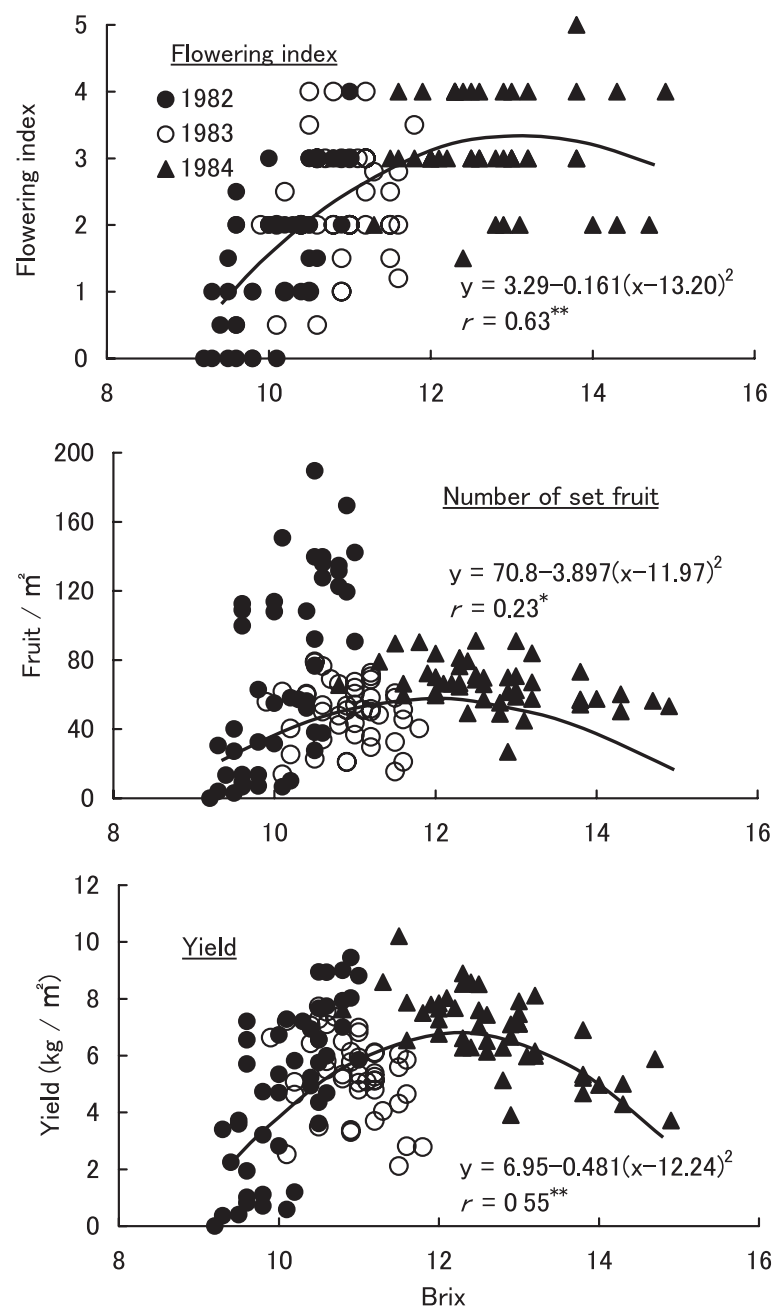

Fig. 3 Relationship between concentration of soluble solids (Brix) in fruit juice and productivity in the next year for 'Aoshima unsyu'.

$*$ and $* *$ indicate significance at $5 \%$ and $1 \%$ levels, respectively.

果実重や糖度は正の相関がみられた。しかし，次年度の結 実数や収量に対しては, 果実重が収量に対して強い正の相 関が認められた以外，相関関係は弱い傾向であった。

次年度の生産性項目を目的变数とし, 生産性項目々果実 形質項目のらち 2 変数を説明変数とする重回帰分析を行 い，重相関係数が最大となる組久合わせ，およびほぼ同程 度の組久合わせがある場合はそれを含めて第 3 表に示し た. 重相関係数が小さかった “宮川早生”を除いて, 第 1 変 数としては果実重が正の関係で，または着花程度が負の関 係で選択され，第 2 変数としては糖度が正の関係で選択さ れる場合が多かった．この場合，糖度の偏相関係数は第 2 表の単相関係数よりいずれも高まっていた，また，少なく とも糖度と次年度着花程度との関係は試験 1 と 2 亿共通し て预り, 相関係数が高かった ‘繁田温州” ‘青島温州’で は, 回帰式から糖度 1 度の上昇につき着花程度は概衫 0.4 
上昇することが示された。

糖度と次年度生産性との関係について, 試験 1 の結果を 第 2 図に示した。糖度は大部分が 9\%から 12\%の範囲で あったが，いずれの品種も糖度が低い樹では次年度着花程 度の変異が大きいものの, 糖度が高い樹では着花程度の低 いことが減少する, といら分布であった. 次年度の結実数 および収量は, 糖度が低い樹では着花程度同様変異が大き く, 糖度が高くなるにつれて中位に収束する傾向の分布で あった．試験 2 に打ける同様の関係を第 3 図に示した. 3 か年を通してみると, 糖度 13 度程度までは次年度の着花程 度が高まるが，それ以上ではほぼ一定の傾向であった。次 年度結実数に対しては, 糖度の上昇が 12 度程度までは結実 数は増加するが，それ以上ではむしろ減少傾向であった。 収量に対しては, 糖度 12 度程度をピークとする放物線的変 化が明瞭であった。

\section{考察}

第 1 表で, 生産性項目や果実形質項目などの全変動に占 める樹間変動の割合がいずれの品種でも小さかったことは 供試した各品種 4 樹の生産力や果実品質は比較的揃ってい たことを表している。したがって, 本試験の栽培条件では, “宮川早生” 数が小さかったことから連年多収型で隔年結果性が弱く, 逆に “青島温州” は平均值が低い上に変動係数が大きかった ことから隔年結果性が強いといえよう. 糖度に着目すると, 試験 1 , 試験 2 ともに全変動に占める年次間変動の割合が 生産性項目に比べて大きく，また，同一年の生産性項目と 糖度の相関関係は弱かった。 これまでの報告においても， 糖度は着果量が多めの樹で高い傾向がみられる（宮田・橋 本，2002）ものの, 無摘果の場合は着果量に汇とんど左右 されない事例（森岡，1987, 1988）もある. これらから糖度 は，隔年結果などによる着果量の違いよりも気象などの年 次に特有な要因に影響される度合いが大きい項目と推定さ れる.

第 2 表で単相関に着目すると, 着果負担の指標となる生 産性項目と次年度の生産性項目との間には当然のことなが ら負の相関がみられた。しかし相関係数が全般に“宮川早 生’では低く，“青島温州’では高かったことは，本報のよ らな栽培条件では“宮川早生’は隔年結果性が弱く, ‘青島 温州'は強いことによるものであろら。また，生育初期の 着花程度が関係する相関係数は高く, 結実数から収穫果数, 収量に至る生育後期の項目が関係する相関係数ほど低下傾 向であったことは, 隔年結果性は着花を含む春季の発芽状 態として現れ，その状態の影響が強く残り，摘果などによっ て収穫果数や収量は変わってもその影響は比較的小さい (森岡, 1989）ことによるのであろう。 また, 果実重は次年 度生産性と正の強い相関関係が認められた。 これまでに, 果実重は着果程度と負の相関関係にあり（岩崎，1961; 清 水ら, 1975), 特に摘果以前の着果程度との関係が強い（森
岡，1989）とする報告があり，果実重は早期からの着果負 担を表す指標の一つと考えられる。糖度は次年度生産性と 概ね正の関係ではあったが，相関係数は他の項目に比べる と比較的小さく, 糖度単独では次年度生産性との相関関係 は大きくない.

次年度の生産性項目を目的変数とする重回帰分析で最大 の重相関係数を示す 2 説明変数の組み合わせ（第 3 表）は， 試験 1 では第 1 説明変数として果実重, 第 2 説明変数とし て糖度が最も多く，試験 2 でも次年度着花程度に対しては 着花量と糖度の組み合わせであった，加えて，他方の要因 との関連を除外した糖度と次年度着花程度との相関の強さ を表す偏相関係数は単相関係数（第 2 表）より高まった. これらから糖度は, 重回帰分析で着果負担を表す主要な要 因の補足要因として取り入れる場合に有効性が高まるもの と考えられる。

糖度と次年度生産性との関係を第 2 図, 第 3 図で総合す ると, 糖度 12 度まではいずれの品種も糖度が高いほど次年 度着花程度は高いこと, また, 結実数や収量も “繁田温州” や“青島温州”では増加する傾向であることが示された. しかし糖度が 12 度を超えて高まると, 少なくとも“青島温 州’では，着花程度は確保されるが結実数および収量は減 少する傾向のあることが示された。過度の糖度上昇は過度 の水分ストレスなどの結果（谷口，1971; 富田，1972a）で あることが想定され, 冬季の落葉を助長し（山田ら，1987）, 春季の新葉発生も少なく(富田, 1972a), 着花よりも結実へ の影響が大きいとされる冬季から春季の着葉量（新居・岡 本，1973；清水ら，1976）の減少を招き，生産性の低下に 結びつくものといえよう.

以上より，“繁田温州’や青島温州’では, 糖度が次年度 の生産性を予測する指標として有効であることが判明し た。ただし，次年度生産性を左右する主要因はあくまでも 着果負担であり, 糖度はそれを補足する要因である。また, 糖度は全変動に占める年次間変動の割合が他の項目より大 きく，着果負担などの樹ごとに異なる影響よりも，同じ年 度ではどの樹も共通して受ける気象などの環境要因の影響 が大きいと推察される，したがって糖度は，樹体養分の場 合と同様（岡田，2004），園地内に抢ける樹体間の生産性の 変動よりも，環境要因が異なる園地間や年次間に打ける生 産性の変動を対象とする場合により有効な指標になるもの と考えられる。また，収穫時点の糖度が試験 1 の 10 年間で は最も高いグループの值である 12 度程度までは次年度の 生産性も高まることが認められたことから，栽培技術によ るこの程度までの高品質化も安定生産と両立する可能性が 推察された.

\section{摘 要}

ウンシュウミカン “宮川早生”, “繁田温州”, “青島温州”に おいて，着果負担を表すものと想定される生産性項目（着 花程度, 結実数, 収穫果数, 収量) および果実重, 果汁の 
糖度と次年度の生産性項目 (着花程度, 結実数, 収量) との 間の関係について, 特に果汁の糖度に着目して解析した. “宮川早生”では生産性項目の変動が小さく, 明確な関係は みられなかった。 ‘繁田温州”と ‘青島温州’では, 次年度の 生産性項目に対して, 生産性項目は負の相関が, 果実重お よび糖度は正の相関が認められた. 重回帰分析により, 次 年度の生産性は主として着果負担の軽重に左右されるが, 補足要因として糖度が有効であり, 高い重相関係数が認め られた。相関図より, 次年度の着花程度は糖度が高くなる ほど高く, 結実数や収量も糖度 12 度程度までは増加するこ と，ただし，“青島温州”において糖度が 12 度を超えて高 まる樹では次年度の結実数や収量は減少する傾向であるこ とが示された. 以上より, “繁田温州” と “青島温州”では 糖度は次年度の生産性を予測する指標として有効であり, 収穫時の糖度12度程度までの高品質化は安定生産と両立す ることが推察された。

\section{引用文献}

Goldschmidt, E. E. and A. Golomb. 1982. The carbohydrate balance of alternate-bearing citrus trees and the significance of reserves for flowering and fruiting. J. Amer. Soc. Hort. Sci. 107: 206-208.

岩崎藤助. 1961. カンキッの隔年結果防止に関する研究 (第 4 報) 摘果が隔年結果の防止に及ぼす影響. 園学雑. 30 : 103-110.

木原武士・岩垣 功・奥田 均・河瀬憲次. 1995. ウンシュ ウミカンの部分全摘果による群状結実技術一隔年結果 防止及び果実品質向上効果. 果樹試報. 27: 11-26.

宮田明義・橋本和光. 2002. 交互結実法が ‘青島温州” 若 齢樹の生育, 収量および果実品質に及ぼす影響. 園学 雑. 71: 789-795.

森岡節夫. 1987. ウンシュウミカン若木の着果程度及び摘 果が果実の形質, 翌年の着花などに及ぼす影響. 園学
雑. 56: 1-8.

森岡節夫. 1988. ウンシュウミカン成木の着果程度及び摘 果が果実の大きさ及び形質，翌年の着果などに及ぼす 影響. 園学雑. 57: 351-359.

森岡節夫. 1989. ウンシュウミカンの摘果直前の着果程度 が果実の大きさ，収量及び翌年の着花などに及ぼす影 響. 園学雑. 58: 97-103.

新居直祐・岡本 茂. 1973. 温州ミカンの樹体成長および 開花・結実に及ぼす葉齢と摘葉処理の影響. 園学雑. 42: 7-12.

岡田正道. 2004. ウンシュウミカンの生産性予測要因とし ての樹体養分の有効性. 園学雑. 69: 624-628. 園学雑. 73: $163-170$.

清水達夫・鳥潟博高・鳥居鎮男. 1975. 温州ミカンの着果 負担に関する研究 (第 3 報) 葉果比が収穫期の樹体内 炭水化物含量ならびに翌春の着花数・新葉数に及ぼす 影響. 園学雑. 43: 423-429.

清水達夫・鳥潟博高・鳥居鎮男. 1976. 温州ミカンの着果 負担に関する研究 (第 4 報) 着果樹と不着果樹の物質 生産過程について. 園学雑. 45: 123-134.

谷口哲微. 1971. カンキッのかん水に関する研究（第 2 報） かん水, 乾燥処理と温州ミカン果実の発育, 収量, 品 質について. 静岡柑橘試研報. 9:27-37.

富田栄一. 1972a. 温州ミカンの果実の品質および翌年の開 花に扣よぼす夏季の土壌水分と秋季の窒素施肥時期の 影響. 園学雑. 41: 151-156.

富田栄一. 1972b. かん水が温州ミカン成木の果実の収量, 品質抒よび葉内成分に及ぼす影響. 園学雑. 41:353360.

山田 寿・向井啓雄・杉浦 明・苫名 孝. 1987. カンキ ツの耐寒性に及ぼす水ストレスの影響. 園学雑. 56 : 273-279. 